\title{
Systematic comparison of sporadic and syndromic pancreatic islet cell tumors
}

\begin{abstract}
Zoran Erlic*, Ursula Ploeckinger ${ }^{*}$, Alberto Cascon ${ }^{2,3}$, Michael M Hoffmann ${ }^{4}$, Laura von Duecker, Aurelia Winter, Gerit Kammel, Janina Bacher, Maren Sullivan, Berend Isermann ${ }^{5}$, Lars Fischer ${ }^{6}$, Andreas Raffe ${ }^{7}$, Wolfram Trudo Knoefel ${ }^{7}$, Matthias Schott ${ }^{8}$, Tobias Baumann ${ }^{9}$, Oliver Schaefer ${ }^{9}$, Tobias Keck ${ }^{10}$, Richard P Baum ${ }^{11}$, loana Milos ${ }^{12}$, Mihaela Muresan ${ }^{13}$, Mariola Peczkowska ${ }^{14}$, Andrzej Januszewicz ${ }^{14}$, Kenko Cupisti ${ }^{7}$, Anke' Tönjes ${ }^{15}$, Mathias Fasshauer ${ }^{15}$, Jan Langrehr ${ }^{16}$, Peter von Wussow ${ }^{17}$, Abbas Agaimy ${ }^{18}$, Günter Schlimok ${ }^{19}$, Regina Lamberts ${ }^{20}$, Thorsten Wiech ${ }^{21}$, Kurt Werner Schmid ${ }^{22}$, Alexander Weber, Mercedes Nunez, Mercedes Robledo ${ }^{2,3, t^{\prime}}$, Charis Eng ${ }^{23,}+$, Hartmut P H Neumann ${ }^{\dagger}$ for the VHL-ICT Consortium and the German NET Registry
\end{abstract}

\footnotetext{
Section of Preventive Medicine, Department of Nephrology, Albert-Ludwigs-University, Hugstetter Strasse 55, D-79106 Freiburg, Germany

${ }^{1}$ Department of Hepatology and Gastroenterology, Interdisciplinary Centre of Metabolism: Endocrinology, Diabetes and Metabolism, Charité-Universitätsmedizin Berlin, Campus Virchow-Klinikum, Charitéplatz 1, D-10117 Berlin, Germany

${ }^{2}$ Hereditary Endocrine Cancer Group, Spanish National Cancer Center, Melchor Fernández Almagro 3, 28029 Madrid, Spain

${ }^{3}$ ISCIII Center for Biomedical Research on Rare Diseases (CIBERER), Sinesio Delgado 4-6, 29029 Madrid, Spain

${ }^{4}$ Department of Laboratory Medicine, Albert-Ludwigs-University, Hugstetter Strasse 55, D-79106 Freiburg, Germany

Departments of ${ }^{5}$ Internal Medicine I and Clinical Chemistry and ${ }^{6}$ Surgery, Ruprecht-Karls-University, Im Neuenheimer Feld 110, D-69120 Heidelberg, Germany

Departments of ${ }^{7}$ General and Visceral Surgery and ${ }^{8}$ Endocrinology, Diabetes and Rheumatology, University Hospital Düsseldorf, Moorenstraße 5, D-40225 Düsseldorf, Germany

Departments of ${ }^{9}$ Diagnostic Radiology and ${ }^{10}$ Visceral Surgery, Albert-Ludwigs-University, Hugstetter Strasse 55, D-79106 Freiburg, Germany

${ }^{11}$ Department of Nuclear Medicine/Center for PET, Zentralklinik Bad Berka, Robert Koch Allee 9, D-99437 Bad Berka, Germany

${ }^{12}$ Department of Endocrinology of the University of Medicine and Pharmacy Victor Babes, I. Bulbuca Boulevard 10,

300736 Timisoara, Romania

${ }^{13}$ Department of Endocrinology, Hospital Sainte Blandine, Cambout 3, 57046 Metz, France

${ }^{14}$ Institute of Cardiology, Ul. Alpejska 42, 04-638 Warsaw, Poland

${ }^{15}$ Medical Clinic 3, University of Leipzig, Philipp Rosenthalstrasse 42, D-04103 Leipzig, Germany

${ }^{16}$ Department of Surgery, Evangelisches Waldkrankenhaus Spandau, Stadtrandstrasse 555, D-13589 Berlin, Germany

${ }^{17}$ Private Practice, Rösebeckstrasse 15, D-30449 Hannover, Germany

${ }^{18}$ Department of Pathology, University of Erlangen, Krankenhausstrasse 12, D-91054 Erlangen, Germany

${ }^{19}$ Medical Clinic 2, City Hospital, Stenglinstrasse 2, D-86156 Augsburg, Germany

${ }^{20}$ Klinikum Peine gGmbH, Medical Clinic II, Gastroenterology, Virchowstrasse 2, D-86156 Peine, Germany

${ }^{21}$ Institute of Pathology, Albert-Ludwigs-University, Hugstetter Strasse 55, D-79106 Freiburg, Germany

${ }^{22}$ Institute of Pathology and Neuropathology, University Hospital of Essen, University of Duisburg-Essen, Hufelandstrasse 55, D-45122 Essen, Germany

${ }^{23}$ Genomic Medicine Institute, Lerner Research Institute, and Taussig Cancer Institute, Cleveland Clinic, 9500 Euclid Avenue, Cleveland, Ohio 44195, USA
}

(Correspondence should be addressed to H P H Neumann who is now at Medizinische Universitätsklinik, Abteilung Innere Medizin 4, Hugstetter Strasse 55, D-79106 Freiburg, Germany; Email: hartmut.neumann@uniklinik-freiburg.de)

*(Z Erlic and U Ploeckinger contributed equally to this work)

${ }^{\dagger}$ (M Robledo, C Eng and H P H Neumann share senior authorship of this work)

\begin{abstract}
Pancreatic islet cell tumors (ICTs) occur as sporadic neoplasias or as a manifestation of multiple endocrine neoplasia type 1 (MEN1) and von Hippel-Lindau disease (VHL). Molecular classification of ICTs is mandatory for timely diagnosis and surveillance. Systematic comparison of VHL-ICTs and sporadic ICTs has been lacking. Our registry-based approaches used the German NET-Registry with 259 patients with neuroendocrine tumors (NETs), who were primarily
\end{abstract}


diagnosed with NETs, and the German VHL-Registry with 485 molecular genetically confirmed patients who had undergone magnetic resonance imaging or computed tomography of the abdomen. All patients provided blood DNA for testing of the MEN1 and VHL genes for intragenic mutations and large deletions. In the NET-Registry, 9/101 patients $(8.9 \%)$ with ICTs had germline mutations, 8 in MEN1 and 1 in VHL. In the VHL-Registry, prevalence of NETs was 52/487 (10.6\%), and all were ICTs. Interestingly, of those with VHL p.R167W, 47\% developed ICTs, compared to $2 \%$ of those with p.Y98H. In total, there were 92 truly sporadic, i.e. mutation-negative ICT patients. Comparing these with the $53 \mathrm{VHL}-\mathrm{ICT}$ patients, the statistically significant differences were predominance of female gender $(P=0.01)$, multifocal ICTs $(P=0.0029)$, and lower malignancy rate $(P<0.001)$ in VHL-ICTs compared to sporadic cases. VHL was prevalent in $<0.5 \%$ of NETs, while NETs occur in $\sim 10 \%$ of VHL, virtually exclusively as ICTs, which are rarely the first presentation. Patients with NETs should not be subjected to genetic testing of the VHL gene, unless they have multifocal ICTs, other VHL-associated tumors, and/or a family history for VHL.

Endocrine-Related Cancer (2010) 17 875-883

\section{Introduction}

Islet cell tumors of the pancreas (ICTs) are neuroendocrine tumors (NETs), which are classified into three entities: 1) ICT as sporadic tumor; 2) ICT as a component of multiple endocrine neoplasia type 1 (MEN1; Chandrasekharappa et al. 1997, Brandi et al. 2001); and 3) ICT in patients with von Hippel-Lindau disease (VHL; Doherty 2005, Woodward \& Maher 2006, Blansfield et al. 2007, Corcos et al. 2008, Toumpanakis \& Caplin 2008). MEN1 and VHL are autosomal dominant diseases affecting several organs, whereas the etiological background in sporadic ICTs remains to be clarified. In contrast to the wellrecognized sporadic and MEN1-associated ICTs, ICT as a component of VHL has not been systematically investigated. In this context, it may also be noteworthy that coincidence of extra-pancreatic NETs has rarely been reported in patients with VHL (Kees 1980, Cheng et al. 1997). Comprehensive studies, however, on the prevalence of VHL in patients with NETs and their characteristics have yet to be performed.

As with all heritable neuroendocrine neoplasia syndromes in the 21 st century, recognition of VHL is mandatory because gene-based risk assessment and organ-specific surveillance and interventions reduce morbidity and mortality. Major manifestations of VHL are hemangioblastoma of the retina and the central nervous system (CNS), renal clear cell carcinoma, pheochromocytoma and paraganglioma, multiple pancreatic cysts, ICTs, endolymphatic sac tumor of the inner ear, and cystadenoma of the epididymis and broad ligament. The susceptibility gene, VHL, is located in 3p25-26 comprising three exons and encoding the 213-amino acid VHL protein. The germline mutations are scattered throughout the gene. Potentially, malignant VHL-associated tumors, e.g. leading to distant metastases, are renal clear cell carcinoma, malignant pheochromocytoma, and ICTs (reviewed by Lonser et al. (2003)).

In this study, we sought to evaluate a populationbased registry of patients with NETs for the prevalence of gene-defined VHL and MEN1. In parallel, we interrogated a population-based registry of VHL for the prevalence of NETs. Finally, we compared the demographic and clinical characteristics of truly sporadic ICTs and those with MEN1- and VHLassociated ICTs in order to help define guidelines for offering molecular genetic testing of the $V H L$ gene in patients presenting with ICTs as well as the necessity of pancreatic screening in individuals with VHL.

\section{Methods}

\section{Registries}

\section{The NET-Registry}

Incepted in 2003, German endocrinology, gastroenterology, and oncology centers registered their NET patients into the NET-Registry. Patients were registered with demographic and clinical data including age at onset, gender, location, number and size of the tumor, and benign or malignant status (Plöckinger et al. 2010). All registrants from 1 November 2005 until 31 October $2008(n=259)$ were offered mutation analysis of the MEN1 and VHL genes. In addition, the NET-Registry was open to patients from other countries, which only represent about $3 \%$ of the total entries.

\section{The VHL-Registry}

Founded in 1983, the VHL-Registry based in Freiburg was established by a nation-wide networking of ophthalmologists, neurosurgeons, endocrinologists, and geneticists. Criteria for inclusion were a proven germline 
mutation of the VHL gene. Since 1983, ascertainment and registration included $>95 \%$ of all patients with VHL in Germany. In addition, as of 1998, the VHLRegistry was also open to patients from other countries, representing about $5 \%$ of the total entries.

\section{Clinical data}

The diagnosis of ICTs in NET-Registry patients was based on histopathological confirmation in all cases. In contrast, in the VHL-Registry, solid pancreatic tumors were diagnosed as ICTs by histological confirmation and/or imaging since no other solid pancreatic tumors have been described in VHL, and surgery is only recommended for patients with tumors of a considerable size (Hammel et al. 2000, Libutti et al. 2000, Lonser et al. 2003). Thus, the common phenotype of ICTs in both the registries is the radiologically solid tumor of the pancreas, but in contrast to the ICTs in the NET-Registry all of which were confirmed by histology, in VHL-associated ICTs, histology was not obligatory.

Clinical data included demographic data, personal and family history for neoplasias, tumor imaging, laboratory-measured hormonal status before surgery, histopathological findings, and follow-up data. Basic investigations included gadolinium-enhanced magnetic resonance imaging (MRI) of the abdomen and the set of gastrin, C-peptide, and insulin measurements using standard assays. The diagnosis of a malignant neuroendocrine pancreatic tumor was based on the presence of metastases.

Patients with VHL underwent additional clinical investigation, which included retinoscopy, gadoliniumenhanced MRI of the brain and spinal cord, as well as catecholamine measurement in the $24 \mathrm{~h}$ urine.

\section{Molecular genetic analyses}

All registrants provided $10 \mathrm{ml}$ EDTA-anticoagulated blood for molecular genetic analyses. The analyses comprised testing of all exons including the splice sites of the VHL (RefSeq:NM_000551.2) and MEN1 (RefSeq:NM_130803.1) genes for germline mutations. DNA extraction, primers, PCR conditions, and sequencing methods followed published protocols of international standards (Lemmens et al. 1997, Franke et al. 2009). The primers are available on request. Of note, analyses also included screening for large deletions or rearrangements of the $V H L$ and MEN1 genes. For screening for intragenic mutations, we used the PCRbased denaturing HPLC. For detection of large deletions/rearrangements, we used two commercially available kits for multiplex ligation-dependent probe amplification, the SALSA MLPA KIT P016 VHL, and the SALSA MLPA KIT P017-B1 MEN1 respectively (MLPA, MRC Holland, Amsterdam, The Netherlands). The primers are available on request. All analyses for the $V H L$ gene and the analyses for intragenic mutations in the MEN1 gene have been performed in Freiburg. The analyses for the large deletions and rearrangements of the MEN1 gene have been performed in Madrid.

\section{Statistical analysis}

We compared the groups of $V H L$ mutation as positive and sporadic ICT patients for differences in the variables age, gender, pancreatic location as first documented manifestation (yes or no), tumor biology (benign and malignant), multiple or single ICT, and family history for VHL, MEN1, or NETs. For comparison of means, we used the $t$-test. Two-tailed Fisher's exact test was used for analysis of categorical data. Missing data were excluded from the analysis.

\section{Approval and consent}

The study design was approved by the ethical committee of the University Medical Center of Freiburg and all participating centers accordingly. The study was performed in accordance with the guidelines of the Helsinki Declaration of 1975, as revised in 1983. For the NET-Registry, a positive ethical consent was acquired at the Charité, Berlin. In addition, official consent from the Berlin Commissioner for Data Protection and Freedom of Information was secured. All patients signed an informed consent form for participation with the registry and an additional form consenting to the genetic analysis.

\section{Role of the funding source}

The funding sources had no role in study design; in the collection, analysis, and interpretation of data; in the writing of the report; and in the decision to submit the paper for publication.

\section{Results}

\section{The NET-Registry}

The 259 unrelated index registrants in the NET-Registry from whom blood DNA was available for molecular genetic analyses formed the basis for our first set of studies addressing the prevalence of VHL and MEN1 in unselected consecutive patients with NETs. Of the 259 subjects, 101 (38.9\%) had ICTs, 42 females and 59 males, with mean age at diagnosis 55.7 years (range 12-82; S.D. 13.1). Of these 101 unrelated patients with 
ICTs from the NET-Registry, 8 were found to carry germline mutations in the MEN1 gene and 1 had a mutation of the $V H L$ gene. The detected MEN1 germline mutations were different in each of the eight cases, namely MEN1 c.322 C > T, p.Arg108X, MEN1 c.333 delT, p.Val112SerfsX7, MEN1 c.640 del26, p.Gly214ProfsX9, MEN1 c.673 G > A, p.G225R, MEN1 c.740 T>C, p.I247T, MEN1 c.758 C > T, p.S253L, MEN1 c.824+1 G>A, and MEN1 c.1546 dupC, p.Ala516ProfsX15. The only patient with VHL-ICT was found to carry the VHL c.349 dupT, W117LfsX15 mutation. Of these mutations, MEN1 c.322 C>T, p.Arg108X*, MEN1 c.673 G>A, p.G225R*, and MEN1 c.824+1 G>A* have already been published. The published mutations are indicated by an * (Giraud et al. 1998, Hai et al. 1999, Crepin et al. 2003). In contrast, molecular genetic analyses of the 158 patients of the NET-Registry with extra-pancreatic NETs did not show any germline mutations of the MEN1 or VHL gene. Major locations of these tumors were jejunum-ileum-coecum in $31 \%$ of the entire NET-Registry, colorectum $8 \%$, appendix $4 \%$, bronchus $3 \%$, stomach $2 \%$, and $12 \%$ were from other sites or unknown primary location. None of the 259 patients of the NET-Registry had signs of neurofibromatosis type 1 or tuberous sclerosis complex.

\section{VHL-Registry}

A total of 485 registrants from the VHL-Registry underwent pancreatic imaging. Of these 485 patients, 224 had pancreatic abnormalities. Multiple pancreatic cysts or cystadenoma were demonstrated in 171 subjects. ICT was present in $53(11 \%)$ subjects, 10 of whom also had pancreatic cysts.

The 52 index cases, 34 female and 18 male, were diagnosed with ICTs at mean age of 36.8 years (range $13-75$, s.D. 12.5). Forty (76\%) subjects had a single ICT, whereas 12 subjects had multiple ICTs.

All 52 patients were diagnosed with VHL due to clinical symptoms caused by tumors in other organs; in addition, 11 VHL patients had symptoms due to the pancreatic tumor later in life. Malignant ICTs occurred in 13 of the 52 index cases. Of these 13 cases, 11 had liver metastases, 5 had lymph node metastases, and 2 had additional bone metastases.

\section{Patients with mutations of the VHL gene}

The germline VHL mutations of the 53 VHL patients with ICTs, 52 from the VHL-Registry and 1 from the NET-Registry, are shown in Table 1 . These 53 patients harbored 30 different intragenic mutations, 21 missense, and 9 truncating mutations, and in addition
6 large deletions ranging from deletion of 1 to all 3 exons. Interestingly, while the VHL-Registry expectedly has a predominance of the $\mathrm{Y} 98 \mathrm{H}$ founder mutation observed frequently in the Black Forest region (35\%), only $1 \%$ of those with this mutation developed ICTs. In contrast, $47 \%$ of those with hot spot mutation R167W developed ICTs. Excluding the 158 registrants with the $\mathrm{Y} 98 \mathrm{H}$ founder mutation, a clustering of mutations at codons 160-167 (19/53 ICT patients vs 34/296 VHL registrants) was present.

Associated tumors in the $53 \mathrm{VHL}$ patients with ICTs included retinal hemangioblastomas in $34(64 \%)$ cases, CNS hemangioblastomas in $44(81 \%)$, renal clear cell carcinoma in 20 (37\%), pheochromocytoma in $29(53 \%)$, endolymphatic sac tumor of the inner ear in $1(1.8 \%)$, cystadenomas of the epididymis in $3(5.5 \%)$ and broad ligament tumor in $2(3.7 \%)$ subject. These figures do not differ statistically from the 432 VHL patients in this study without ICTs from the VHL-Registry: retinal hemangioblastomas 213/394 (54\%), CNS hemangioblastomas 246/400 (62\%), renal clear cell carcinoma 88/416 (21\%), pheochromocytoma 148/416 (36\%), endolymphatic sac tumor of the inner ear $6 / 339(2 \%)$, and cystadenomas of the broad ligament or the epididymis $21 / 344(6 \%)$.

\section{Comparison of demographic and clinical data in sporadic ICTs and VHL-associated ICTs}

The demographic and clinical data of 53 patients with VHL-associated ICTs and 92 patients with apparently sporadic ICTs (those in whom germline mutations of the MENI and VHL genes have been excluded by this study) are shown in Table 2 . The mean age at diagnosis of ICTs was 37 (s.D. 12.5) years for the VHL group and 57 (s.D. 12.0) years for the sporadic group $(<0.001)$. Patients with VHLassociated ICTs were more frequently female (VHL 34/54 vs sporadic 37/92, $P=0.01$ ), had more multifocal ICTs (VHL $13 / 54$ vs sporadic 5/92; $P=0.0029)$, and had fewer instances of malignant tumors (VHL 14/54 vs sporadic 68/92, $P=<0.001$ ) compared to sporadic ICT patients.

\section{Comparison of demographic and clinical data in VHL- and MEN1-associated ICTs}

Although based on small numbers of MEN1-related ICT patients $(n=8)$, VHL-related ICTs had fewer instances of malignancy than those found in MEN1 (14/53 vs $6 / 8, P=0.012$ ). There were no significant differences in gender distribution, age at diagnoses, single vs multifocal tumors, and family histories between ICT patients with VHL and those with 
Table 1 von Hippel-Lindau disease (VHL) germline mutations in VHL patients with islet cell tumors (ICTs)

\begin{tabular}{|c|c|c|c|c|}
\hline Nucleotide change & Consequence & $\begin{array}{l}\text { VHL patients } \\
\text { with ICTs }\end{array}$ & $\begin{array}{l}\text { Patients with the given } \\
\text { mutation in this study }\end{array}$ & References \\
\hline c. $208 \mathrm{G}>\mathrm{T}^{\mathrm{a}}$ & p.E70X & 1 & 1 & Chen et al. (1995) \\
\hline c. $221 \mathrm{~T} / \mathrm{G}^{\mathrm{a}}$ & p.V74G & 1 & 4 & Glavac et al. (1996) \\
\hline c.440_442delTCT & p.F76CfsX83 & 1 & & \\
\hline c. $240 \mathrm{~T}>\mathrm{G}^{\mathrm{a}}$ & p.S80R & 1 & 2 & Crossey et al. (1994) \\
\hline c. $266 \mathrm{~T} / \mathrm{C}^{\mathrm{a}}$ & p.L89P & 1 & 7 & Crossey et al. (1994) \\
\hline c. $277 \mathrm{G}>\mathrm{C}^{\mathrm{a}}$ & p.G93R & 1 & & Klein et al. (2001) \\
\hline c. $292 \mathrm{~T}>\mathrm{C}^{\mathrm{a}}$ & p.Y98H & 2 & 158 & Crossey et al. (1994) \\
\hline c. $340 \mathrm{G}>\mathrm{A}^{\mathrm{a}}$ & p.G114S & 1 & 1 & Blanco et al. (2004) \\
\hline c.349dupT & p.W117LfsX1 & 1 & 1 & \\
\hline c. $357 \mathrm{C}>\mathrm{G}^{\mathrm{a}}$ & p.F119L & 2 & 2 & Chen et al. (1995) \\
\hline c. $362 A>G^{a}$ & p.D121G & 1 & 1 & Whaley et al. (1994) \\
\hline c.364_365 GC $>$ AT & p.A122I & 1 & 1 & \\
\hline c. $393 \mathrm{C}>\mathrm{A}^{\mathrm{a}}$ & p.N131K & 1 & & Gallou et al. (2004) \\
\hline c. $394 \mathrm{C}>\mathrm{T}^{\mathrm{a}}$ & p.Q132X & 1 & & Glavac et al. (1996) \\
\hline c.445_458del14 & p.N150SfsX19 & 1 & 2 & \\
\hline c. $453 \mathrm{C}>\mathrm{G}$ & p.I151M & 1 & 1 & \\
\hline c. $461 \mathrm{C}>\mathrm{T}^{\mathrm{a}}$ & p.P154L & 1 & 4 & Crossey et al. (1994) \\
\hline c. $464-2 A>G^{a}$ & Splice & 2 & 4 & Glavac et al. (1996) \\
\hline c. $467 \mathrm{~A}>\mathrm{G}^{\mathrm{a}}$ & p.Y156C & 1 & & Neumann et al. (2002) \\
\hline c. $472 \mathrm{C}>\mathrm{G}^{\mathrm{a}}$ & p.L158V & 1 & 1 & Crossey et al. (1994) \\
\hline c.478_479delGA & p.E160AfsX12 & 2 & 3 & \\
\hline c. $482 \mathrm{G}>\mathrm{A}^{\mathrm{a}}$ & p.R161Q & 5 & 8 & Chen et al. (1995) \\
\hline c. $488 \mathrm{~T}>\mathrm{A}^{\mathrm{a}}$ & p.L163H & 1 & 2 & Chen et al. (1995) \\
\hline c. $499 \mathrm{C}>\mathrm{T}^{\mathrm{a}}$ & p.R167W & 7 & 15 & Crossey et al. (1994) \\
\hline c. $500 \mathrm{G}>\mathrm{A}^{\mathrm{a}}$ & p.R167Q & 4 & 5 & Crossey et al. (1994) \\
\hline$c .533 \mathrm{~T}>\mathrm{C}^{\mathrm{a}}$ & p.L178P & 1 & 1 & Crossey et al. (1994) \\
\hline c. $548 \mathrm{C}>\mathrm{A}^{\mathrm{a}}$ & p.S183X & 1 & 4 & Whaley et al. (1994) \\
\hline c.583 C> $>\mathrm{T}^{\mathrm{a}}$ & p.Q195X & 1 & 3 & Crossey et al. (1994) \\
\hline c. $593 \mathrm{~T}>\mathrm{A}^{\mathrm{a}}$ & p.L198Q & 2 & & Neumann et al. (2002) \\
\hline Large deletions $^{\mathrm{b}}$ & & 6 & 63 & \\
\hline
\end{tabular}

andicates mutations that have been already published.

bindicates deletions of 1,2 , or 3 exons of the $V H L$ gene.

MEN1 ( $P=0.2-1.0$; Table 3). The hormone status for blood levels of gastrin, $\mathrm{C}$ peptide, and insulin was known from all 8 (7 insulinomas) MEN1, 16 VHL, and 72 patients with sporadic ICTs. In the MEN1 group, seven patients had insulinomas; in the VHL group, all patients were without elevated hormone levels; in the patients with sporadic ICTs, four patients had insulinomas, three gastrinomas, three glucagonomas, two vipomas, and twb Zollinger-Ellison syndrome.

\section{Discussion}

Both NETs and paraganglial tumors are of neural crest origin, but the pathogenesis appears to be only partially overlapping. With respect to NETs and paraganglial tumor predisposition, NETs are frequent tumors in MEN1 (Brandi et al. 2001), whereas paraganglial tumors are associated with VHL, MEN2, neurofibromatosis type 1 , and the paraganglioma syndromes type 1, 2, 3, and 4 (Erlic \& Neumann 2009). In contrast, pancreatic ICTs are typical component tumors of MEN1 and VHL. Very rarely, ICTs have also been reported in neurofibromatosis type 1 and tuberous sclerosis complex (Perren et al. 2006, Dworakowska \& Grossman 2009). However, studies on large series of patients with systematic molecular genetic analyses for germline mutations in the genes MEN1 and VHL were pending.

In this study, we used a series of 744 patients from two population-based registries, the VHL-Registry based in Freiburg with 485 patients and the German NET-Registry with 259 patients, all of whom had DNA and relevant clinical data available. These two registries were selected for purposes of this study so that we are able to answer specific hypotheses. It is important to note that the two registries are completely different registries that, naturally enough, have different eligibility criteria for registration. The NET-Registry registers all comers with histologically confirmed NETs from any anatomic site, irrespective of other features or family history. For purposes of our study, 
Table 2 Comparison between VHL-related and sporadic islet cell tumors

\begin{tabular}{llll}
\hline Variables & VHL & Sporadic & $\boldsymbol{P}$ value \\
\hline Age (years) & & & \\
Mean & 36.8 & 57.07 & \\
S.D. & 12.49 & 11.98 & \\
Sex & & & \\
Female & 34 & 37 & 0.001 \\
Male & 19 & 55 & \\
Tumor number & & & \\
Single & 41 & 87 & $\mathbf{0 . 0 0 2 9}$ \\
Multiple & 12 & 5 & \\
Tumor biology & & & \\
Benign & 39 & 24 & \\
Malignant & 14 & 68 & \\
Pancreatic tumor as first presentation & \\
Yes & 2 & 92 & $<\mathbf{0 . 0 0 1}$ \\
No & 51 & 0 & \\
Family history & of NETs/VHL/MEN1 & \\
Positive & 32 & 1 & $\mathbf{0 . 0 0 1}$ \\
Negative & 21 & 91 & \\
\hline
\end{tabular}

$P$ values considered to be significant are represented in bold. VHL, von Hippel-Lindau disease; MEN1, multiple endocrine neoplasia syndrome type 1; NETs, neuroendocrine tumors.

the database of this registry was then searched for only pancreatic ICTs. This allows us to ask the question among all comers with histologically documented pancreatic ICTs, what is the prevalent frequency of germline MENI and VHL mutations. The second registry is the VHL-Registry whose entry criteria are noted in the section 'Methods', but in brief, registration requires VHL diagnostic criteria and/or germline $V H L$ mutations. This registry notates patients who are operated on for ICTs and thus have histological diagnosis, but it also includes patients not operated on for pancreatic ICTs, mostly smaller than $3 \mathrm{~cm}$ in diameter. This registry allowed us to ask what is the prevalence of ICTs among those with VHL mutations. Owing to our practice guidelines, ICTs smaller than $3 \mathrm{~cm}$ are usually not operated on. These differences of ascertaining ICTs from the NET-Registry and from the VHL-Registry are slightly different, and may, in part, affect our results and conclusions. In particular, the relatively low prevalence of patients with mutations of the MENl gene, perhaps in part due to the strict entry criteria of histological documentation, should initiate confirming studies.

Prevalence of ICTs in the NET-Registry was 101/259 (39\%). While slightly under half of the 259 NETRegistry patients had ICTs, only 1 carried a germline $V H L$ mutation and 8 an MEN1 mutation. The very low frequency of occult germline $V H L$ mutations in sporadic ICT series is confirming the poor involvement of this pathway in the development of the sporadic ICTs (Chung et al. 1997, Giraud et al. 1998, Anlauf et al. 2006). While one could invoke a selection bias to explain these observations, this is unlikely as our registries are essentially population based.

When there is a relatively high frequency (usually $>10 \%$ ) of unexpected germline mutations in a single organ (apparently sporadic) presentation of a neoplasia, the usual practice recommendation is to offer genetic testing to all incident cases in the setting of genetic counseling. This is true for medullary thyroid cancer (Kloos et al. 2009) and pheochromocytoma/ paraganglioma (Neumann et al. 2002, Benn et al. 2006, Burnichon et al. 2009, Erlic et al. 2009, Franke et al. 2009, Mannelli et al. 2009). Therefore, a clinically relevant question is whether $V H L$ and/or MEN1 testing should be offered to all presentations of ICTs. Given the very low frequency of occult mutations in $V H L$ in the NET-Registry, whether it is an ICT presentation (one registrant) or an extra-pancreatic NET presentation (none), our data suggest that $V H L$ testing is not warranted for every NET, even ICT, presentation in the absence of other VHL component features or family history. On the other hand, if an individual already has VHL especially with the R167W mutation, then careful surveillance for ICTs is warranted.

Our study has suggested two distinct, molecular genetically defined groups of patients with ICTs. It is not surprising that VHL-related and MEN1-related ICTs are very similar to each other, but distinct from sporadic ICTs, in regard to younger age at diagnosis and higher frequency multifocal tumors, both

Table 3 Comparison between VHL-related and MEN1-related islet cell tumors

\begin{tabular}{|c|c|c|c|}
\hline Variables & VHL & MEN1 & $P$ value \\
\hline \multicolumn{4}{|l|}{ Age (years) } \\
\hline Mean & 36.8 & 43.88 & \multirow[t]{2}{*}{0.27} \\
\hline $95 \% \mathrm{Cl}$ & 12.49 & 16.21 & \\
\hline \multicolumn{4}{|l|}{ Sex } \\
\hline Female & 34 & 5 & \multirow[t]{2}{*}{1.0} \\
\hline Male & 19 & 3 & \\
\hline \multicolumn{4}{|c|}{ Tumor number } \\
\hline Single & 41 & 4 & \multirow[t]{2}{*}{0.19} \\
\hline Multiple & 12 & 4 & \\
\hline \multicolumn{4}{|c|}{ Tumor biology } \\
\hline Benign & 39 & 2 & \multirow[t]{2}{*}{0.012} \\
\hline Malignant & 14 & 6 & \\
\hline \multicolumn{4}{|c|}{ Family history of NETs/VHL/MEN1 } \\
\hline Positive & 31 & 5 & \multirow[t]{2}{*}{1.0} \\
\hline Negative & 22 & 3 & \\
\hline
\end{tabular}

$P$ values considered to be significant are represented in bold. VHL, von Hippel-Lindau disease; MEN1, multiple endocrine neoplasia syndrome type 1 ; NETs, neuroendocrine tumors. 
hallmarks of heritable neoplasia. Interestingly, there is a predominance of female gender and benign disease in VHL-related ICTs compared to sporadic ICTs. Although the sample size is small for MEN1-related ICTs, it is interesting to preliminarily note that VHLrelated ICTs have a preponderance of benign disease even over MEN1-related ICTs. It is not clear whether the differences in the age at diagnosis and tumor biology are biased by the early and regular clinical check ups that VHL patients undergo, or whether it is a characteristic relevant to the VHL genotype. However, both hypotheses merit further investigation at different levels. In the first case, it could lend proof that VHL patients benefit from regular screening for ICTs, and in the second that VHL-associated pathways might present a protective role for ICT behavior. One hint derives from the preponderance of ICTs in individuals with VHL carrying the p.R167W mutation compared to the relative underrepresentation of ICTs in VHL individuals with the p.Y98H Black Forest founder mutation.

In conclusion, VHL is a rare cause of ICT and extrapancreatic NET. Thus, VHL gene testing in individuals with ICTs or NETs is not indicated unless the patient and/or family have other clinical features of VHL. Surveillance for ICTs with known VHL, however, is likely indicated in patients, in particular those who are female and/or with the R167W mutation. All patients with VHL receive routine abdomino-pelvic surveillance, and so no extra imaging is required, but perhaps vigilance and awareness of ICTs in the VHL setting. In contrast to MEN1- and sporadic ICTs, VHL-related ICTs affect more females than males but are less often malignant.

\section{Declaration of interest}

The authors declare that there is no conflict of interest that could be perceived as prejudicing the impartiality of the research reported.

\section{Funding}

H P H Neumann is supported by a grant from the German Cancer Foundation (Deutsche Krebshilfe) Grant 107995 (H P H Neumann). C Eng is the recipient of a Doris Duke Distinguished Clinical Scientist Award and an NIH-funded researcher.

\section{Author contribution statement}

H P H Neumann, C Eng, Z Erlic, U Plöckinger, A Winter, R P Baum, and M Robledo designed the study, performed the registrations of the patients, performed the analyses, drafted, revised, and approved the final manuscript. The molecular genetic analyses have been performed in the laboratories in Freiburg and Madrid by A Cascon, M M Hoffmann, J Bacher, M Sullivan, A Weber, and M Nunez. Important and detailed informations of patients were provided by B Isermann, L Fischer, A Raffel, W T Knoefel, M Schott, T Baumann, O Schaefer, T Keck, I Milos, M Muresan, M Peczkowska, A Januszewicz, K Cupisti, A Tönjes, M Fasshauer, J Langrehr, P von Wussow, A Agaimy, G Schlimok, R Lamberts, T Wiech, and K W Schmid.

\section{Acknowledgements}

We acknowledge the support of many patients and colleagues, especially of Dr Norbert Grobe, Klinik für Innere Medizin I, Dietrich-Bonhoeffer-Klinikum, Neubrandenburg and Dr Marlies Götz-Schupp, City Hospital, Nürnberg.

\section{References}

Anlauf M, Schlenger R, Perren A, Bauersfeld J, Koch CA, Dralle H, Raffel A, Knoefel WT, Weihe E, Ruszniewski P et al. 2006 Microadenomatosis of the endocrine pancreas in patients with and without the multiple endocrine neoplasia type 1 syndrome. American Journal of Surgical Pathology 30 560-574. (doi:10.1097/01.pas.0000194044. 01104.25)

Benn DE, Gimenez-Roqueplo AP, Reilly JR, Bertherat J, Burgess J, Byth K, Croxson M, Dahia PL, Elston M, Gimm O et al. 2006 Clinical presentation and penetrance of pheochromocytoma/paraganglioma syndromes.

Journal of Clinical Endocrinology and Metabolism 91 827-836. (doi:10.1210/jc.2005-1862)

Blanco JA, Blanco D, Alastrue A, Castellvi A, Isnard RM, Pintos G, Mangas A, Roig N \& Casasa JM 2004 Surgical treatment of a pheocromocytoma bilateral in a 5 year old patient with the von Hippel-Lindau disease. Cirugía Pediátrica 17 45-48.

Blansfield JA, Choyke L, Morita SY, Choyke PL, Pingpank JF, Alexander HR, Seidel G, Shutack Y, Yuldasheva N, Eugeni M et al. 2007 Clinical, genetic and radiographic analysis of 108 patients with von Hippel-Lindau disease (VHL) manifested by pancreatic neuroendocrine neoplasms (PNETs). Surgery 142 814-818 (discussion 818, e811-e812). (doi:10.1016/j.surg.2007.09.012)

Brandi ML, Gagel RF, Angeli A, Bilezikian JP, Beck-Peccoz P, Bordi C, Conte-Devolx B, Falchetti A, Gheri RG, Libroia A et al. 2001 Guidelines for diagnosis and therapy of MEN type 1 and type 2. Journal of Clinical Endocrinology and Metabolism 86 5658-5671. (doi:10. 1210/jc.86.12.5658)

Burnichon N, Rohmer V, Amar L, Herman P, Leboulleux S, Darrouzet V, Niccoli P, Gaillard D, Chabrier G, Chabolle F et al. 2009 The succinate dehydrogenase genetic testing in a large prospective series of patients with paragangliomas. Journal of Clinical Endocrinology and Metabolism 94 2817-2827. (doi:10.1210/jc.2008-2504) 
Chandrasekharappa SC, Guru SC, Manickam P, Olufemi SE, Collins FS, Emmert-Buck MR, Debelenko LV, Zhuang Z, Lubensky IA, Liotta LA et al. 1997 Positional cloning of the gene for multiple endocrine neoplasia-type 1. Science 276 404-407. (doi:10.1126/science.276.5311.404)

Chen F, Kishida T, Yao M, Hustad T, Glavac D, Dean M, Gnarra JR, Orcutt ML, Duh FM, Glenn G et al. 1995 Germline mutations in the von Hippel-Lindau disease tumor suppressor gene: correlations with phenotype. Human Mutation 5 66-75. (doi:10.1002/humu. 1380050109)

Cheng TY, Su CH, Shyr YM \& Lui WY 1997 Management of pancreatic lesions in von Hippel-Lindau disease. World Journal of Surgery 21 307-312. (doi:10.1007/ s002689900234)

Chung DC, Smith AP, Louis DN, Graeme-Cook F, Warshaw AL \& Arnold A 1997 A novel pancreatic endocrine tumor suppressor gene locus on chromosome $3 \mathrm{p}$ with clinical prognostic implications. Journal of Clinical Investigation 100 404-410. (doi:10.1172/JCI119547)

Corcos O, Couvelard A, Giraud S, Vullierme MP, Dermot OT, Rebours V, Stievenart JL, Penfornis A, Niccoli-Sire P, Baudin E et al. 2008 Endocrine pancreatic tumors in von Hippel-Lindau disease: clinical, histological, and genetic features. Pancreas 37 85-93. (doi:10.1097/MPA. 0b013e31815f394a)

Crepin M, Escande F, Pigny P, Buisine MP, Calender A, Porchet N \& Odou MF 2003 Efficient mutation detection in MEN1 gene using a combination of single-strand conformation polymorphism (MDGA) and heteroduplex analysis. Electrophoresis 24 26-33. (doi:10.1002/elps. 200390023)

Crossey PA, Richards FM, Foster K, Green JS, Prowse A, Latif F, Lerman MI, Zbar B, Affara NA, Ferguson-Smith MA etal. 1994 Identification of intragenic mutations in the von Hippel-Lindau disease tumour suppressor gene and correlation with disease phenotype. Human Molecular Genetics 3 1303-1308. (doi:10.1093/hmg/3.8.1303)

Doherty GM 2005 Multiple endocrine neoplasia type 1. Journal of Surgical Oncology 89 143-150. (doi:10.1002/ jso.20181)

Dworakowska D \& Grossman AB 2009 Are neuroendocrine tumours a feature of tuberous sclerosis? A systematic review. Endocrine-Related Cancer 16 45-58. (doi:10. 1677/ERC-08-0142)

Erlic Z \& Neumann HP 2009 Familial pheochromocytoma. Hormones 8 29-38.

Erlic Z, Rybicki L, Peczkowska M, Golcher H, Kann PH, Brauckhoff M, Müssig K, Muresan M, Schäffler A, Reisch $\mathrm{N}$ et al. 2009 Clinical predictors and algorithm for the genetic diagnosis of pheochromocytoma patients. Clinical Cancer Research 15 6378-6385. (doi:10.1158/10780432.CCR-09-1237)

Franke G, Bausch B, Hoffmann MM, Cybulla M, Wilhelm C, Kohlhase J, Scherer G \& Neumann HP 2009 Alu-Alu recombination underlies the vast majority of large VHL germline deletions: molecular characterization and genotype-phenotype correlations in VHL patients. Human Mutation 30 776-786. (doi:10.1002/humu.20948)

Gallou C, Chauveau D, Richard S, Joly D, Giraud S, Olschwang S, Martin N, Saquet C, Chretien Y, Mejean A et al. 2004 Genotype-phenotype correlation in von Hippel-Lindau families with renal lesions. Human Mutation 24 215-224. (doi:10.1002/humu.20082)

Giraud S, Zhang CX, Serova-Sinilnikova O, Wautot V, Salandre J, Buisson N, Waterlot C, Bauters C, Porchet N, Aubert JP et al. 1998 Germ-line mutation analysis in patients with multiple endocrine neoplasia type 1 and related disorders. American Journal of Human Genetics 63 455-467. (doi:10.1086/301953)

Glavac D, Neumann HP, Wittke C, Jaenig H, Masek O, Streicher T, Pausch F, Engelhardt D, Plate KH, Hofler H et al. 1996 Mutations in the VHL tumor suppressor gene and associated lesions in families with von HippelLindau disease from central Europe. Human Genetics 98 271-280. (doi:10.1007/s004390050206)

Hai N, Aoki N, Matsuda A, Mori T \& Kosugi S 1999 Germline MEN1 mutations in sixteen Japanese families with multiple endocrine neoplasia type 1 (MEN1). European Journal of Endocrinology 141 475-480. (doi:10.1530/eje.0.1410475)

Hammel PR, Vilgrain V, Terris B, Penfornis A, Sauvanet A, Correas JM, Chauveau D, Balian A, Beigelman C, O'Toole D et al. 2000 Pancreatic involvement in von Hippel-Lindau disease. The Groupe Francophone d'Etude de la Maladie de von Hippel-Lindau. Gastroenterology 119 1087-1095. (doi:10.1053/gast.2000.18143)

Kees A 1980 Malignant carcinoid and phaeochromocytoma in von Hippel-Lindau's disease - a case report (author's translation). Wiener Klinische Wochenschrift 92 218-221.

Klein B, Weirich G \& Brauch H 2001 DHPLC-based germline mutation screening in the analysis of the VHL tumor suppressor gene: usefulness and limitations.

Human Genetics 108 376-384. (doi:10.1007/ s004390100500)

Kloos RT, Eng C, Evans DB, Francis GL, Gagel RF, Gharib H, Moley JF, Pacini F, Ringel MD, Schlumberger M et al. 2009 Medullary thyroid cancer: management guidelines of the American Thyroid Association. Thyroid 19 565-612. (doi:10.1089/thy.2008.0403)

Lemmens I, Van de Ven WJ, Kas K, Zhang CX, Giraud S, Wautot V, Buisson N, De Witte K, Salandre J, Lenoir G et al. 1997 Identification of the multiple endocrine neoplasia type 1 (MEN1) gene. The European Consortium on MEN1. Human Molecular Genetics 6 1177-1183. (doi:10.1093/hmg/6.7.1177)

Libutti SK, Choyke PL, Alexander HR, Glenn G, Bartlett DL, Zbar B, Lubensky I, McKee SA, Maher ER, Linehan WM et al. 2000 Clinical and genetic analysis of patients with pancreatic neuroendocrine tumors associated with von Hippel-Lindau disease. Surgery 128 1022-1027 (discussion 1027-1028). (doi:10.1067/msy.2000.110239) 
Lonser RR, Glenn GM, Walther M, Chew EY, Libutti SK, Linehan WM \& Oldfield EH 2003 von Hippel-Lindau disease. Lancet 361 2059-2067. (doi:10.1016/S01406736(03)13643-4)

Mannelli M, Castellano M, Schiavi F, Filetti S, Giacche M, Mori L, Pignataro V, Bernini G, Giache V, Bacca A et al. 2009 Clinically guided genetic screening in a large cohort of Italian patients with pheochromocytomas and/or functional or non-functional paragangliomas. Journal of Clinical Endocrinology and Metabolism 94 1541-1547. (doi:10.1210/jc.2008-2419)

Neumann HP, Bausch B, McWhinney SR, Bender BU, Gimm O, Franke G, Schipper J, Klisch J, Altehoefer C, Zerres K et al. 2002 Germ-line mutations in nonsyndromic pheochromocytoma. New England Journal of Medicine 346 1459-1466. (doi:10.1056/NEJMoa020152)

Perren A, Wiesli P, Schmid S, Montani M, Schmitt A, Schmid C, Moch H \& Komminoth P 2006 Pancreatic endocrine tumors are a rare manifestation of the neurofibromatosis type 1 phenotype: molecular analysis of a malignant insulinoma in a NF-1 patient. American Journal of Surgical Pathology 30 1047-1051. (doi:10. 1097/00000478-200608000-00018)

Plöckinger U, Kloeppel G, Wiedenmann B \& Lohmann R 2009 The German NET-Registry: an audit on the diagnosis and therapy of neuroendocrine tumours. Neuroendocrinology 90 349-363. (doi:10.1159/000242109)

Toumpanakis CG \& Caplin ME 2008 Molecular genetics of gastroenteropancreatic neuroendocrine tumors. American Journal of Gastroenterology 103 729-732. (doi:10.1111/ j.1572-0241.2007.01777.x)

Whaley JM, Naglich J, Gelbert L, Hsia YE, Lamiell JM, Green JS, Collins D, Neumann HP, Laidlaw J, Li FP et al. 1994 Germ-line mutations in the von Hippel-Lindau tumorsuppressor gene are similar to somatic von Hippel-Lindau aberrations in sporadic renal cell carcinoma. American Journal of Human Genetics 55 1092-1102.

Woodward ER \& Maher ER 2006 Von Hippel-Lindau disease and endocrine tumour susceptibility. Endocrine-Related Cancer 13 415-425. (doi:10.1677/erc.1.00683) 